
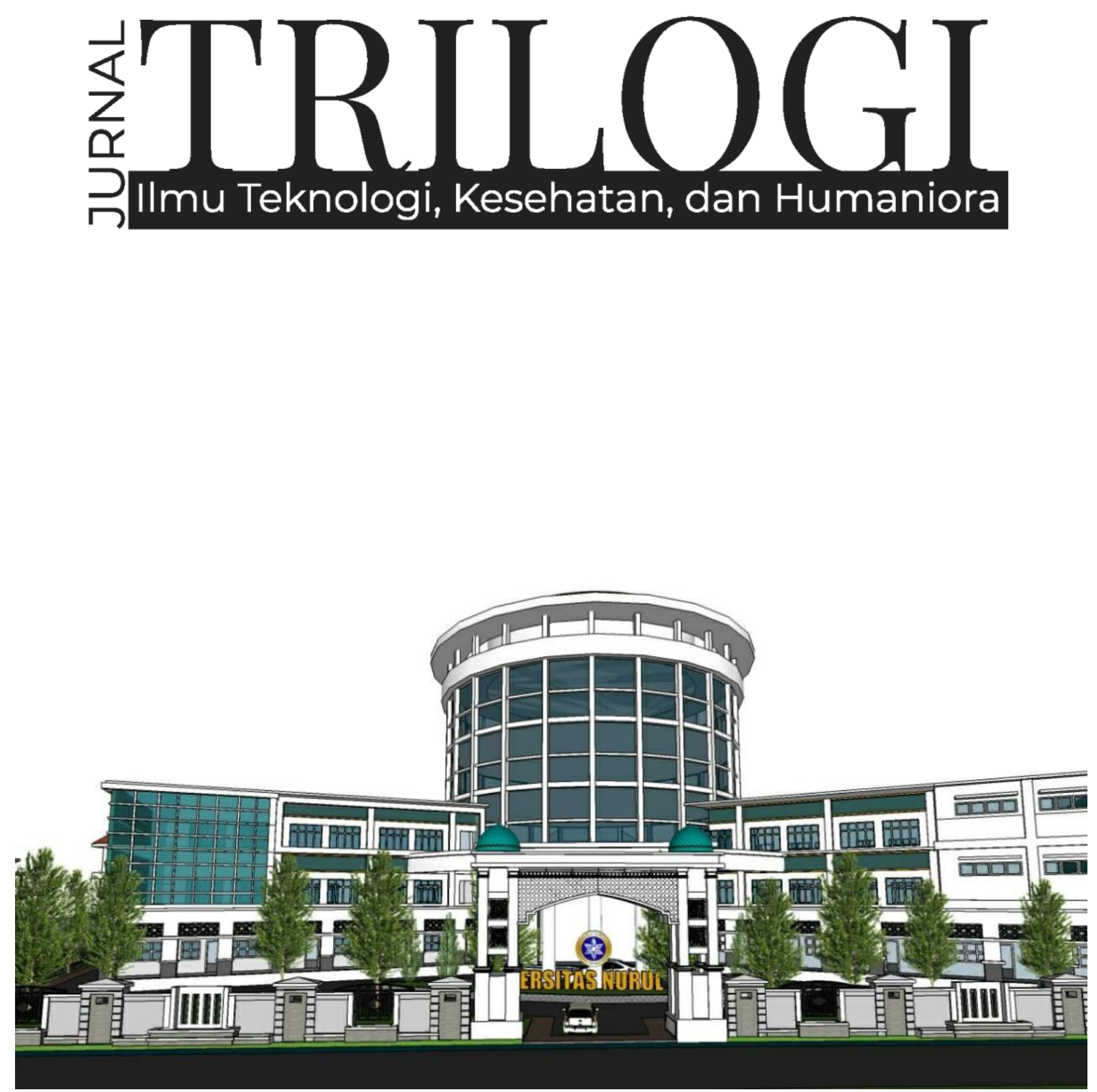

PENGEMBANGAN PENDIDIKAN DAN EKONOMI PESANTREN DI MASA PANDEMI COVID-19 


\section{犃BUOGI}

Vol. 2, No. 2, 2021

Editor in Chief

Achmad Fawaid, (SCOPUS ID: 57214837323)

\section{Managing Editors}

Hasan Baharun, (ID SCOPUS : 57200983602)

Sugiono Sugiono, (SCOPUS ID : 57199578160)

Ismail Marzuki, (SCOPUS ID: 57201500245

Subhan Rachman, (SCOPUS ID: 57192937912)

Nurul Huda, (SINTA ID: 6119615)

Syamsuri, (SINTA ID: 6116825)

Ridhatullah Assya'bani, (SINTA ID: 6200862)

\section{Peer Reviewers}

Miftahul Huda, (SINTA ID: 6171566), University of Antwerp, Belgium

Achmad Naufal Irsyadi, (SINTA ID: 6704870), Universitas Nurul Jadid, Indonesia

Gulpi Qorik Oktagalu P., (SINTA ID: 5982074) Universitas Nurul Jadid Probolinggo, Indonesia Hozairi, (SINTA ID: 166198), Universitas Islam Madura, Indonesia

Nur Hamid, (SINTA ID : 6744813), Univeristas Nurul Jadid Probolinggo, Indonesia Zainal Munir, (SINTA ID: 6672512), Universitas Nurul Jadid Probolinggo, Indonesia Sri Astutik Andayani, (SINTA ID: 6172559), Universitas Nurul Jadid Probolinggo, Indonesia Sukamto Sukamto, (SINTA ID: 5979034), Universitas Widya Gama Malang, Indonesia Deny Utomo, (SINTA ID: 6016108), Universitas Yudharta Pasuruan, Indonesia Fariz Alnizar, (SCOPUS ID: 6659824), UNUSIA Jakarta, Indonesia

Fuad Rahman, (SCOPUS ID: 57201474778), UIN Sulthan Thaha Saifuddin Jambi, Indonesia Saifuddin Zuhri Qudsy, (SCOPUS ID: 57213595165), UIN Sunan Kalijaga Yogyakarta, Indonesia Akhmad Anwar Dani, (SINTA ID: 14305), IAIN Surakarta, Indonesia

Maufur Maufur, (SINTA ID: 5989329), IAIN Kediri, Indonesia

Siti Mahmudah Noorhayati, (SINTA ID: 6726997), IAIN La Roiba Bogor, Indonesia Busro Busro, (SCOPUS ID: 57205022652), UIN Sunan Gunung Djati Bandung, Indonesia Akmal Mundiri, (SCOPUS ID: 57205059378), UNUJA Probolinggo, Indonesia

\section{Section Editor}

Ahmad Zubaidi, Universitas Nurul Jadid, Probolinggo, Indonesia 
TRILOGI: Jurnal IImu Teknologi, Kesehatan, dan Humaniora is a peer-reviewed journal, open-access journal which publishes original articles on various issues within technology, health, and social humanities, which include but are not limited to newrenewable energy, food-agriculture, health-pharmacy, transportation, informationcommunication technology, advanced-materials, maritime-infrastructre, social-artseducation, and religious studies based on academic and scientific research.

TRILOGI: Jurnal IImu Teknologi, Kesehatan, dan Humaniora seeks to publish a balanced mix of theoretical or empirical articles, case studies, review papers, comparative studies, exploratory papers, and book reviews. All accepted manuscripts will be possibly published both online and in printed forms.

Editorial Office:

TRILOGI: Jurnal IImu Teknologi, Kesehatan, dan Humaniora Lembaga Penerbitan, Penelitian, dan Pengabdian kepada Masyarakat (LP3M) Universitas Nurul Jadid, Paiton, Probolinggo, Jawa Timur, Indonesia 67291.

Phone: 088830 77077, Hp: 082318007953

Email: jurnal.trilogi@gmail.com

Website: https://ejournal.unuja.ac.id/index.php/trilogi/index 


\section{Tables of Content}

71-76

Pengaruh Metode Pembelajaran Daring dengan Aplikasi Google Classroom terhadap Hasil Belajar Siswa Madrasah Ibtidaiyah Nurul Mun'im Paiton Probolinggo

Feriska Listrianti, Lailatul Munawwaroh, Sayyidatul Arifa, Siti Aisyah

77-84

Inklusivitas dan Responsivitas Pesantren dalam Penanganan Pandemi Covid 19: Telaah Hidden Curriculum Pembelajaran di Pondok Pesantren Nurul Jadid

Zakiyah BZ, Uswatun Hasnah, Nafistur Rahmah

84-94

Integrasi Kurikulum Madrasah Diniyah dengan Lembaga Formal dalam Meningkatkan Mutu Lulusan di Sekolah Menengah Pertama (SMP) Nurul Jadid Paiton Probolinggo

Abdurrahman, Ika Fitri Anwar, Sofiya Mauliza, Nadya Afkarina

95-104

Some Issues on Time Deposit Financing: An Islamic Perspective on Mudharabah Agreement at Baitul Maal wa Tamwil (BMT) NU in Randuagung Lumajang

Saifuddin, Abdul Hafid, Hengki Wahyu Pratama

$105-110$

Analisis Pengembangan Potensi Ekonomi Keluarga melalui Unit Usaha Kapuk

Fahrudin, Iis Sa'diyah, Rizaldi Chandra Gunawan

111-117

Penguatan Ekonomi Pesantren melalui Pengembangan Ekonomi Masyarakat Pesisir: Pelajaran dari Pondok Pesantren Nurul Jadid Paiton Probolinggo

Achmad Febrianto, Muhammad Habibullah, Aksal Ilhamsyah

118-125

Prevensi Perilaku Konsumtif Persepektif Abraham Maslow dan Tri Logi Santri

Muhammad Syaiful Suib, Habibatur Rizkiyah, Fitria Nur Ain 
$126-136$

Manajemen Pengembangan Kurikulum Berorientasi pada Pembentukan Karakter

Moh Rifa'i, Fatimah Al Zahra, Abdurrahman Abdurrahman, Mukhlisin Saad

137-147

Home Industry, Kaderisasi, dan Santripreneur

Muh Hamzah, Aprilinda Dwi Kurniawati, Husnul Khotimah

148-157

Rancangan Pengelolaan Nirsampah Mandiri Skala Lembaga Pendidikan

Tirmidi, Eril Sinta Nuriyah, Rofi'ah

158-166

Parents' Knowledge and Commitment To Stimulate Child Development

Lailatul Fitriyah, Nurul Islamiyah, Auliya' Fatahillah

167-172

Implementasi Pembelajaran Akhlak Berbasis Multikultural pada Masa Pandemi di Madrasah Tsanawiyah Nurul Jadid Paiton Probolinggo

Abdullah, Yusrolana, Nur Laily

$173-183$

Implementasi Evaluasi Pembelajaran Daring (Online) melalui Home Visit

Moch Tohet, Moh. Bagus Abdillah, Adam Hakim Al Rizki

184-192

Efektivitas Pembelajaran Luring pada Mata Pelajaran Matematika selama Pandemi Covid-19

Zaenol Fajri, Sukron Junaidi, Hamdani Alfarisi 
P-ISSN: 2774-4574; E-ISSN: 2774-4582

TRILOGI, 2(2), Mei-Agustus 2021 (126-136) @2021 Lembaga Penerbitan, Penelitian, dan Pengabdian kepada Masyarakat (LP3M) Universitas Nurul Jadid Paiton Probolinggo

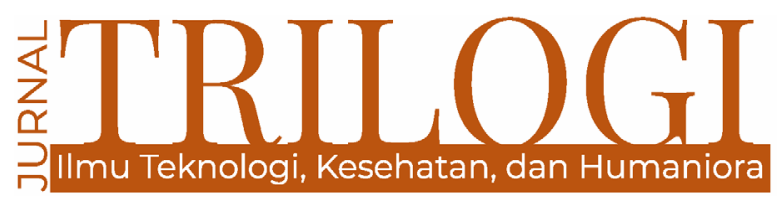

\title{
MANAJEMEN PENGEMBANGAN KURIKULUM BERORIENTASI PADA PEMBENTUKAN KARAKTER
}

\section{Moh. Rifa'i}

Universitas Nurul Jadid, Probolinggo mohrifaiahmad@unuja.ac.id

\section{Fatimah Al Zahra}

Universitas Nurul Jadid, Probolinggo mohrifaiahmad@unuja.ac.id

\author{
Abdurahman \\ Universitas Nurul Jadid, Probolinggo \\ mohrifaiahmad@unuja.ac.id \\ Mukhlisin Saad \\ Universitas Islam Negeri Sunan Ampel Surabaya \\ mukhlisin.saad@uinsby.ac.id
}

\begin{abstract}
The form of human character cannot just be born with good behavior. Good characters need to be embedded and accustomed to humans, where he always move and interact with each other. Educational institutions through the program are the right places for planting and good character habits. But this situation cannot be done by one person. All elements of the highest structure to the lowest in educational institutions must be able to take the time, capable, andwill to participate in making good characters be created in each of the students. Therefore it is necessary to policies and develop the development of a planned character-based curriculum in the educational institution. The discussion in this article was analyzed through various references (libraries) on the management of contemporary character education, strengthened through observation and interviews with several contemporary educational institutions. The findings of this study explained that the management of curriculum development which is oriented to character formation can be done through a combination of integrated methods in the curriculum, among others, the Uswatun Hasanah (Role Model) method, Experiential Learning, icon and affirmation (icon and affirmation), strength Kharisma (Charismatic Power), 99 Asma'ul Husna (99 Names of Allah), Build a Value Agreement of excellence, and the use of metaphors while still paying attention to character education values in each subject, principle, and innovation of curriculum development oriented to good character formation for students.
\end{abstract}

Keyword: Management; Curriculum development; Character building 


\begin{abstract}
Abstrak
Wujud karakter manusia tidak dapat begitu saja lahir dengan perilaku yang baik. Karakter baik perlu ditanamkan dan dibiasakan selalu terjadi pada manusia, di mana ia selalu beraktivitas dan berinteraksi bersama sesamanya. Lembaga pendidikan melalui programnya merupakan tempat yang tepat untuk penanaman dan pembiasaan karakter yang baik. Namun keadaan ini tidak bisa dilakukan oleh satu orang saja. Semua elemen dari struktur tertinggi sampai terendah pada lembaga pendidikan harus bisa menyempatkan, mampu, dan berkemauan untuk berpartisipasi dalam menjadikan karakter baik itu tercipta pada setiap diri peserta didik. Oleh karena itu perlu kebijakan dan manajemen pengembangan kurikulum berbasis karakter yang terencana pada lembaga pendidikan tersebut. Pembahasan dalam artikel ini dianalisis melalui berbagai referensi (pustaka) tentang manajemen pendidikan karakter kontemporer, dikuatkan melalui observasi dan interview terhadap beberapa pihak pemangku lembaga pendidikan kontemporer. Temuan penelitian ini menjelaskan bahwa manajemen pengembangan kurikulum yang berorientasi pada pembentukan karakter dapat dilakukan melalui kombinasi metode yang integrated dalam kurikulum antara lain, metode uswatun hasanah (role model), simulasi praktik (experiential learning), ikon dan afirmasi (icon and affirmation), kekuatan kharisma (charismatic power), 99 Asma'ul Husna (99 Names of Allah), membangun kesepakatan nilai keunggulan, dan penggunaan metafora dengan tetap memperhatikan nilai-nilai pendidikan karakter pada setiap mata pelajaran, prinsip, dan inovasi pengembangan kurikulum berorientasi pada pembentukan karakter baik bagi peserta didik.
\end{abstract}

Katakunci: Manajemen; Pengembangan Kurikulum; Pembentukan Karakter

\section{Pendahuluan}

Ketika Allah SWT berdialog bersama dengan para Malaikat untuk menjadikan manusia sebagai khalifah (pengelola dan pemimpin) di bumi.

"Malaikat Berkata: mengapa Engkau hendak menjadikan di bumi orang-orang yang akan berbuat kerusakan dan menumpahkan darah, padahal kami senantiasa bertasbih, memuji, dan mensucikan Engkau? lalu Allah SWT berkata: Sesungguhnya Aku mengetahui apa yang tidak kamu ketahui."

"Maha Kuasa Allah SWT dengan segala kehendaknya. Manusia hidup di dunia diberi amanah oleh Allah SWT menjadi khalifah, berfungsi sebagai pengelola bumi dan berusaha bagaimana dapat menjalankan fungsinya dengan baik dengan tata cara menggali dan mengembangkan potensi yang ada pada dirinya termasuk mengkaji dirinya sendiri, (IImu, 2013)".

Sejak dahulu sampaik dengan masa kontemporer ini, kita merasakan problem terjadinya kemerosotan moral yang meluas di berbagai lapisan masyarakat bahkan pada tataran birokrasi pemerintah yang membutuhkan penanganan cepat. Hal itu semua berimplikasi terhadap kerugian yang sangat besar. Seperti manusia yang tidak berkualitas dan tidak berkontribusi bagi lingkungannya, kerugian bagi bangsa, masyarakat sekitarnya, dan bahkan kebangkrutan bagi Negara ini dan peradaban Islam tinggal menunggu waktu (Siswanto, 2016). Penanganan yang cepat yang bisa dilakukan adalah dengan menegakan hukum yang adil bagi semua lapisan masyarakat serta memberikan keteladanan dari elit politik dan tokoh masyarakat tentang pentingnya moral bangsa. Namun hal itu tidak cukup, usaha ini harus disertai dengan kegiatan secara terus menerus berupa pendidikan tentang karakter dan moral baik (Kasali, 2015). Metode pendidikan dan komitmen kuat yang dikonsep dalam manajemen pengembangan kurikulum perlu dilakukan dalam membentuk karakter baik pada diri setiap peserta didik oleh para pendidik, dimulai sejak dini dengan pembiasaan-pembiasaan baik dalam kehidupan sehari-hari (Nurrohmah, 2018).

Berangat dari problem tersebut, maka menjadi sangat penting sekali bagi kita sebagai makhluk yang berakal untuk merefleksikan kodrat ini agar tidak sama dengan makhluk-mahkluk Allah SWT yang tidak berakal (Akhiruddin, 2015). Dengan cara mengelola pengembangan kurikulum pada lembaga-lembaga pendidikan yang berorientasi pada peningkatan kualitas karakter baik peserta didik. Jelas di dalam dialog di atas Allah SWT sangat memuliakan manusia di atas derajat seluruh makhluk-Nya.

Lembaga pendidikan merupakan wadah di mana manusia dididik, dibiasakan, diajar mana yang baik dan buruk, bahkan dibentuk agar dapat mempunyai perilaku yang baik, yaitu karakter 
manusia yang sempurna (Huda, 2018). Melalui lembaga pendidikan karakter tersebut dapat dibangun, dibentuk, kemudian menjadi budaya perilaku yang baik sesuai dengan apa yang diperintahkan oleh Allah SWT sebagai Sang Maha Pencipta. Tentunya, pengelola lembaga pendidikan perlu melakukan pendekatan-pendekatan yang baik.

Lembaga pendidikan mempunyai rancangan pekerjaan dalam mendidik para peserta didiknya yang disebut dengan kurikulum (Abdurrahman, 2018). Kurikulum tersebutlah yang kemudian menjadi pedoman inti sebuah lembaga pendidikan dalam rangka membangun karakter baik pada diri setiap peserta didiknya. Tentunya, pengembangan kurikulum harus disusun dengan tujuan yang jelas melibatkan berbagai pihak yang profesional.

Penelitian ini bertujuan guna memberikan kontribusi-kontribusi positif yang aplikatif dalam mengembangkan kurikulum dengan fokus penelitian bagaimana manajemen pengembangan kurikulum yang berorientasi pada pembentukan karakter baik pada sebuah lembaga pendidikan secara universal.

\section{Metode}

Penelitian dengan metode pustaka menjadi cara yang relevan bagi peneliti untuk menghasilkan karya ilmiah dalam suasana pandemic Covid-19 seperti saat ini. Penelitian ini dilakukan saat ini dengan berpedoman kepada problematikaproblematika manajemen kurikum dalam membentuk karakter peserta didik, dan ini terus berkembang tanpa batas sehingga memerlukan perhatian khusus peneliti lain dari waktu ke waktu guna merelevansikan perkembangan yang terjadi.

Metode ini diimplementasi dengan cara mempelajari berbagai referensi atau hasil penelitian yang bermanfaat untuk mendapatkan gambaran konsep mengenai pembahasan dalam penelitian. Pengumpulan data juga dilakukan dengan menelaah buku, jurnal, dan berbagai laporan penelitian yang berkaitan untuk dipecahkan.

Peneliti mengkaji secara teoritis bahan yang ada di perpustakaan secara manual maupun digital dan sistematis untuk mengumpulkan, menganalisis, dan menarik kesimpulan dengan menggunakan metode atau teknik tertentu guna mencari jawaban atas pembahasan yang dikaji. Secara spesifik peneliti melakukan hal-hal berikut: 1. Mencatat temuan mengenai analisis kebutuhan konsumen pada pembahasan penelitian yang diperoleh dari sumber-sumber dan temuan terbaru mengenai masalah penelitian.

2. Mengintegrasikan temuan yang peneliti dapatkan.

3. Menganalisis temuan tentang analisis kebutuhan konsumen tersebut, baik berkenaan dengan kelebihan atau hubungan masingmasing.

4. Mengkritisi teori terdahulu dan memberikan ide kritis dengan menghadirkan temuan baru yang diperoleh peneliti, terutama dalam mengkolaborasikan ide yang berbeda dengan analisis kebutuhan konsumen dalam meningkatkan omset usaha ritel.

\section{Hasil dan Pembahasan}

\section{A. Karakter dalam Pendidikan}

Karakter dalam kamus ilmiah popular dimaknai sebagai watak, tabi'at, pembawaan, dan kebiasaan (Bariah \& Assya'bani, 2019). Makna tersebut dalam dunia pendidikan diarahkan kepada perilaku yang terpuji di hadapan manusia, dan terutama di hadapan Allah SWT. Karena pendidikan adalah usaha menjadikan manusia yang berakhlaq mulia atau berperilaku sempurna sebagai makhluk yang berakal, mengiringi cita-cita manusia untuk dapat dicapainya dengan kesempurnaan dalam segala aspek kehidupan.

Pendidikan karakter, dapat kita pahami sebagai tindakan melakukan penanaman nilai-nilai kehidupan yang baik bahkan sempurna seperti pengetahuan, kesadaran, kemauan, dan tindakan melakukan nilai-nilai tersebut dalam kehidupan sehari baik itu kepada Allah SWT, kepada diri sendiri, kepada sesama manusia, kepada lingkungan sekitar, dan kepada segala hal yang ada di sekitar kita. Sehingga hal tersebut menjadi karakter berperilaku baik dalam kehidupan seharihari guna menggapai ridla Allah SWT.

Menurut Komala dalam bukunya "Pendidikan Karakter: Strategi Membangun Karakter Bangsa Berperadaban", mendefinisikan pendidikan karakter sebagai pendidikan yang menanamkan dan mengembangkan karakter-karakter luhur kepada anak didik, sehingga mereka mempunyai karakter luhur itu, menerapkan dan mempraktekkan dalam kehidupannya baik di keluarga, masyarakat, dan Negara (Komala, Budiyanto, Wibowo, Praditya, \& Pamungkas, 2020).

Maka berdasarkan pengertian di atas, dapat diambil suatu kesimpulan bahwa pendidikan karakter merupakan sebuah sistem penanaman nilai-nilai karakter yang baik kepada peserta didik sehingga mereka dapat menerapkan 
dalam kehidupannya, baik di keluarga, sekolah, masyarakat, dan Negara (I. Abdullah, 2003). Hal ini diharapkan dapat memberikan kontribusi positif pula bagi dirinya sendiri, bagi orang lain di sekitarnya, dan bahkan bagi lingkungannya. Ia kemudian menjadi rahmatan lil alamin, tidak hanya mendatangkan kebaikan untuk dirinya sendiri, namun bahkan untuk orang lain di sekitarnya.

\section{Metode dalam Membangun Karakter}

Upaya yang dapat dilakukan dalam rangka mengelola manajemen kurikulm dalam membangun karakter baik pada diri peserta didik, menurut Budiman, bisa dilalui dengan beberapa metode berikut ini (Mochammad Arif Budiman, 2017):

\section{a. Keteladanan (Uswatun Hasanah)}

Metode yang paling efektif dan kuat dari pada metode lainnya. Bagaimana menjadi contoh baik bagi anak didik, yang dimulai dari diri sendiri. Dalam Islam uswatun hasanah yang dimulai dari diri sendiri menjadi keharusan bagi setiap Muslim karena bila tidak, maka akan menjadi kemudharatan saja bagi dirinya. Hal itu merupakan perbuatan memerintah tapi tidak melaksanakannya. Sebagaimana firman Allah SWT:

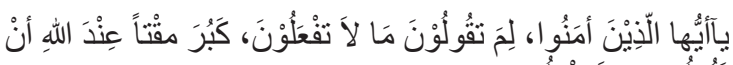

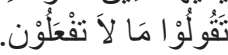

Artinya: "Wahai orang-orang yang beriman, kenapa kamu mengatakan sesuatu yang tidak kamu kerjakan? Amat besar kebencian di sisi Allah SWT bahwa kamu mengatakan apa yang tidak kamu kerjakan." (QS. as-Shaff: 02-03.)

\section{b. Simulasi Praktik (Experiential Learning)}

Confucius mengatakan: "What I hear, I forget. What I see, I remember. What I do, I understand. Membangun karakter dengan tata cara mengajak peserta didik memainkan peran (Role play) sikap yang positif. Dalam Islam hal ini menjadi prioritas dengan ungkapan:

$$
\text { الطَّرِيْقةُُ أَهَمْ مِنَ المَادَة. }
$$

Artinya: "Metode/cara itu lebih penting dari pada materi"

Rancanglah berbagai kegiatan atau program yang dapat memerankan peserta didik berperilaku baik. Hal ini dapat dilakukan dengan tata cara berkoordinasi dan berkomunikasi melibatkan bagian-bagian penting di lembaga pendidikan yang bersangkutan dengan kegiatan yang akan dilakukan. Lakukanlah survey-survey pendahuluan terhadap lembaga-lembaga yang telah menjalankan kegiatan tersebut dan konseplah sesuai dengan kemampuan, yaitu dengan menggunakan analisis S.W.O.T.

\section{c. Ikon dan Afirmasi}

Metode membentuk karakter menggunakan gambar atau tulisan motivatif yang ditempelkan atau digantungkan pada beberapa sudut strategis bangunan, sarana, dan prasarana di lingkungan lembaga pendidikan yang Anda kelola. Hal ini bertujuan agar peserta didik bisa selalu melihat gambar serta tulisan tersebut, mudah dilihat sehingga muncul motivasi dari dalam diri (Motivasi intrinsik) untuk berperilaku yang terbaik dalam kehidupannya sehari-hari. Tentunya gambar dan tulisan harus mudah dipahami. Maka perlu mempelajarinya, bagaimana membuat gambar dan memasukkan tulisan ke dalam poster atau pamflet dan sebagainya.

\section{d. Repear Power}

Metode dengan cara mengungkapkannya berulang-ulang kali dalam berbagai pertemuan, contohnya rapat, upacara, dan sebagainya yang ada di lingkungan lembaga pendidikan. Contoh saya bisa!, saya the best dst. Perilaku seperti ini biasa dilakukan pada instansiinstansi Negara Jepang, yang dianggap sebagai salah satu cara untuk mencapai kesuksesan dengan cara menanamkan pesan positif dan motivatif atau provokatif. Atau mungkin dengan tata cara menggunakan perangkat auditorial yang sudah paten terpasang pada beberapa titik bangunan lembaga pendidikan. Selalu diperdengarkan, diperdengarkan, dan akhirnya hafal dan melaksanakan motivasi tersebut.

\section{e. 99 Sifat Utama (Asma'ul Husna)}

Melakukan penguatan komitmen nilai-nilai dan sikap positif berdasarkan pada sifat utama yaitu "Asma'ul Husna. "Salah satu caranya adalah dengan cara memilih satu asma' yang akan dipraktekkan pada hari yang diinginkan, dan seterusnya secara bergantian. Maka susunlah menjadi pedoman berupa kurikulum praktis dan sistematis. 


\section{f. Membangun Kesepakatan Nilai Keunggulan}

Menetapkan sebuat komitmen untuk membangun nilai-nilai positif yang akan dijadikan suatu karakter yang dibudayakan dalam hidup atau kerja sehari-hari, khususnya di lingkungan lembaga pendidikan. Bisa dilakukan secara bersama-sama oleh seluruh warga internal lembaga pendidikan. Hal seperti ini perlu melibatkan pimpinan lembaga pendidikan. Mulai dari menyusunnya sampai dengan mensosialisasikannya untuk dilaksanakan bersama-sama. Tidak boleh sendiri-sendiri, karena sangat mungkin tidak berjalan dengan baik.

\section{g. Penggunaan Metafora}

Menyampaikan suatu kisah/cerita dari kisahkisah nyata dan inspiratif secara rutin kepada peserta didik atau seluruh warga internal lembaga pendidikan. Ini perlu dilakukan oleh setiap guru mata pelajaran dengan mengintegrasikan materinya dengan karakter yang baik. Maka guru yang membina mata pelajaran umum bisa saling bekerjasama dengan guru yang membina mata pelajaran agama. Dengan prinsip satu sama lain saling membutuhkan untuk pengembangan kurikulum berbasis karakter.

\section{Pendidikan Karakter dalam Pendidikan Agama Islam}

Relasi pendidikan karakter dengan PAI (Pendidikan Agama Islam) dan Budi Pekerti dapat dilihat dalam dua sisi, yaitu materi dan proses belajar mengajar. Dari segi mata pelajaran PAI dan Budi Pekerti bisa mencakup nilai-nilai pendidikan karakter. Hal ini bisa dilihat dalam tabel berikut (Muddin, 2019):

\section{Nilai Pendidikan Karakter dalam Pendidikan Agama Islam (PAI)}

\begin{tabular}{|c|c|c|}
\hline No & Aspek & Nilai Pendidikan Karakter \\
\hline 1 & Alquran & "Religius, Jujur, Toleransi, Disiplin, Kerka Keras, Kreatif, dan Mandiri." \\
\hline 2 & Aqidah & $\begin{array}{l}\text { "Religius, jujur, toleransi, disiplin, kerja keras, kreatif, mandiri, demokratis, rasa ingin tahu, } \\
\text { semangat kebangsaan, cinta tanah air, menghargai prestasi, bersahabat/ komunikatif, cinta } \\
\text { damai, gemar membaca, peduli lingkungan, peduli sosial, tanggung jawab." }\end{array}$ \\
\hline 3 & Akhlak & $\begin{array}{l}\text { "Sopan dan santun dalam bersikap, selalu berkata jujur, mengerjakan apa yang dikatakan, } \\
\text { menghargai orang lain, tidak ghibah, tidah mencela dan menjelekkan sesama, cinta damai, } \\
\text { peduli lingkungan, peduli sosial, bertanggungjawab, dan sebagainya." }\end{array}$ \\
\hline 4 & Fiqih & $\begin{array}{l}\text { "Religius, jujur, toleransi, disiplin, kerja keras, kreatif, mandiri, demokratis, rasa ingin tahu, } \\
\text { semangat kebangsaan, cinta tanah air, menghargai prestasi, bersahabat/komunikatif, cinta } \\
\text { damai, gemar membaca, peduli lingkungan, peduli sosial, tanggung jawab." }\end{array}$ \\
\hline 5 & SKI & $\begin{array}{l}\text { "Cinta para pejuang dan pahlawan, jujur, moderat, disiplin, mau bekerja keras, kreatif } \\
\text { dan produktif, mandiri, moderat dan demokratis, mempunyai rasa ingin tahu, semangat } \\
\text { kebangsaan, cinta tanah air, menghargai prestasi, bersahabat dan komunikatif, cinta damai, } \\
\text { merujuk pada sejarah salafus sholeh, peduli lingkungan, peduli sosial, dan tanggung jawab." }\end{array}$ \\
\hline
\end{tabular}

\section{B. Manajemen Pengembangan Kurikulum Berbasis Karakter}

\section{Perkembangan Kurikulum}

Kurikulum merupakan rencana atau rancangan mata pelajaran yang akan diberikan kepada segenap peserta didik. Ia merupakan seperangkat rencana pendidikan mengenai tujuan, isi, dan bahan pelajaran serta cara yang akan digunakan sebagai pedoman penyelenggaraan PBM (Proses Belajar Mengajar) untuk mencapai tujuan pendidikan yang dicanangkan dalam perintisan lembaga pendidikan. Hal ini sesuai dengan Undang-undang tentang sistem pendidikan Nasional (Mundiri \& Hasanah, 2018). Di zaman kontemporer ini kurikulum terdiri atas 2 macam, yaitu kurikulum Nasional yang telah menjadi ketentuan dari Negara, dan yang kedua adalah kurikulum bermuatan lokal, yaitu rancangan kurikulum yang ditentukan oleh pihak lembaga pendidikan dalam rangka menyesuaikan komponen-komponen pendidikan yang ada agar mempunyai keunikan tertentu dan dapat mencapai suatu misi lembaga pendidikan.

Adapun perkembangan kurikulum yang ada di Indonesia dapat penulis kemukakan sebagai berikut (Adawiyah, 2016):

a. Rencana Pelajaran 1947; diberi nama Rencana Pembelajaran 1947 (leer plan). Rencana pelajaran pada tahun 1947 ini adalah lanjutan dan merupakan kurikulum yang telah digunakan oleh Belanda. Di mana pada saat itu masih dalam proses perjuangan merebut kemerdekaan. Ciri utamanya adalah lebih menekankan pembentukan karakter manusia yang berdaulat dan sejajar dengan bangsa lain. Perubahan kisi-kisi pendidikan lebih bersifat politis. Asas pendidikan ditetapkan Pancasila

b. Rencana Pelajaran Terurai 1952. Rencana pelajaran ini lebih merinci setiap mata pelajaran 
yang disebut Rencana Pelajaran Terurai 1952. Lalu 12 tahun kemudian lahir Kurikulum 1964 di mana hal ini terjadi pada penghujung era Presiden Soekarno. Fokusnya adalah pada pengembangan daya cipta, rasa, karsa, karya, dan moral (Pancawardhana). Mata pelajaran diklasifikasikan dalam lima kelompok bidang studi, yaitu moral, kecerdasan, emosionalatau artistik, keprigelan (Keterampilan), dan badan.

c. Kurikulum tahun 1968 merupakan perkembangan dari pada kurikulum tahun 1964. Dalam hal tersebut dilakukan perubahan struktur kurikulum pendidikan dari Pancawardhana menjadi pembinaan jiwa pancasila, pengetahuan dasar, dan kecakapan khusus, perwujudan dari perubahan orientasi pada pelaksanaan UUD 1945 secara murni dan konsekuen. Tujuan pendidikan diarahkan dan ditekankan pada usaha untuk membentuk manusia yang berkarakter Pancasila. Karakter peserta didik sejati, sehat jasmani dan rohani, mempertinggi kecerdasan otak dan keterampilan jasmani, moral, budi pekerti, dan keyakinan dalam beragama.

d. Kurikulum 1975. Kurikulum ini difokuskan pada penekanan tujuan yang ingin dicapai, dengan maksud agar proses pendidikan berjalan secara efektif dan efisien. Hal yang melatarbelakanginya adalah pengaruh konsep bidang manejemen pendidikan, yaitu MBO (Management by Objective). Segala tindakan diarahkan pada tujuan yang akan ditentukan. Bahan, metode, dan tujuan pendidikan dianalisis dan dirinci dalam bentuk PPSI (Prosedur Pengembangan Sistem Instruksional) yang telah ditetapkan jauh sebelumnya

e. Kurikulum 1984 (Rahman, 2012); Mengusung process skill approach. Kurikulum ini seringkali dikenal dengan sebutan "Kurikulum 1975 yang disempurnakan." Posisi peserta didik ditempatkan sebagai subjek belajar yang mandiri dan tidak selalu bergantung pada tranfermasi materi dari guru. Dari mengamati sesuatu, mengelompokan, mendiskusikan, hingga melaporkan hasil kegiatan belajar mengajar, semua dilakukan oleh peserta didik dimonitoring guru. Model ini dikenal dengan sebutan CBSA (Cara Belajar Siswa Aktif) atau SAL (Student Active Leaming).

f. Kurikulum 1994 dan Suplemen Kurikulum 1999. Kurikulum ini berkembang dengan tujuan yang menekankan pada upaya memadukan antara kurikulum-kurikulum sebelumnya. Konsepnya adalah ingin mengkombinasikan antara Kurikulum 1975 dan Kurikulum 1984.

g. Kurikulum 2004; yaitu Kurikulum Berbasis Kompetensi (KBK). Setiap mata pelajaran dikendalikan dan dianalisis berdasar kompetensi yang seharusnya dicapai oleh peserta didik. Dan kerancuan akan muncul bilamana hal tersebut dikaitkan dengan alat ukur kompetensi peserta didik, yaitu ujian.

h. KTSP 2006. Awal tahun 2006 diujicobakan KBK (Kurikulum Berbasis Kompetensi) dihentikan. Maka muncullah KTSP (Kurikulum Tingkat Satuan Pendidikan). Namun pelajaran KTSP masih tersendat. Hal yang membedakan antara kedua kurikulum ini adalah yang paling menonjol pada gurunya. Mereka lebih leluasa dan diberikan kebebasan untuk merencanakan pembelajaran sesuai dengan kondisi peserta didik, kondisi fasilitas berupa sarana dan prasarana, dan kondisi lingkungan lembaga pendidikan.

i. Kurikulum 13 (K-13), yaitu kurikulum yang lebih dikembangkan kembali berdasarkan perkembangan zaman yang menitikberatkan pada konsep karakter yang diharapkan terdapat pada diri para anak didik. Saat ini kurikulum ini masih diujicobakan pada beberapa sekolah saja.

\section{Prinsip-prinsip dalam mengembangkan Kurikulum Berbasis Karakter}

Dalam inovasi mengembangkan kurikulum berbasis pendidikan karakter, terdapat berbagai prinsip yang bisa dijadikan pedoman sebagaimana dikemukakan sebagai berikut (Subandi, 2014):

a. Karaktermu ditentukan oleh apa yang kamu lakukan, bukan apa yang kamu katakan atau yakini. Prinsip ini ingin memberikan verifikasi kongkrit tentang karakter seseorang individu dengan memberikan prioritas pada unsur psiko-motorik yang menggerakan seseorang untuk bertindak.

b. Setiap keputusan yang kamu ambil akan menjadi orang macam apa dirimu. Individu mengungkapkan karakter pribadinya melalui setiap keputusan yang diambilnya. Hanya dari keputusannya inilah seorang individu mendefinisikan karakternya sendiri. Oleh karena itu, karakter seseorang itu bersifat dinamis.

c. Karakter yang baik mengacu pada konsep bahwa setiap hal yang baik itu dilakukan dengan cara-cara yang baik pula. Bahkan seandainya harus membayar dengan harga yang mahal. Pribadi yang berproses membentuk dirinya menjadi manusia yang baik, juga akan memilih 
cara-cara yang baik bagi pembentukan dirinya.

d. Jangan pernah mengambil risiko buruk yang dilakukan orang lain sebagai patokan bagi dirimu. Kamu dapat melihat patokan lebih baik dari mereka. Tekanan sosial dan kelompok sebaya menjadi arena yang ramai bagi pergulatan pendidikan karakter di sekolah. Kultur non-edukatif yang berlangsung terus dalam lembaga sebuah pendidikan jika segera tidak diatasi akan menjadi standar perilaku para siswa. Demikian juga tekanan kelompok sebaya sangat memengaruhi siswa dalam mengembangkan pendidikan karakter yang berguna bagi dirinya sendiri.

e. Apa yang kamu lakukan itu mempunyai arti dan transformatif. Seorang individu bisa mengubah dunia.Para siswa perlu disadarkan bahwa setiap tindakan yang berkarakter, setiap tindakan yang bernilai, dan setiap perilaku yang bermoral yang mereka lakukan mempunyai arti yang bersifat transformatif.

f. Ganjaranbagi manusia yang mempunyai karakter baik adalah bahwa ia menjadi orang yang mulia di hadapan Allah SWT dan manusia lainnya. Dengan keberadaannya lingkungan di mana ia tinggal menjadi lingkungan yang Islami, nyaman untuk dihuni dan menjadi dambaan setiap manusia untuk menetap di dalamnya.

\section{Model Inovasi Pengembangan Kurikulum Berbasis Karakter}

Implementasi kurikulum pendidikan yang berbasis pada karakter pada lembaga pendidikan secara universal merupakan bagian terikat dari program manajemen peningkatan mutu berbasis sekolah yang terimplementasi dalam pengembangan kurikulum, pelaksanaan, dan evaluasi kurikulum oleh setiap lembaga pendidikan dalam memberikan layanan pendidikan yang memuaskan (Abdurahman, 2017). Pembinaan karakter pada peserta didik dapat dilakukan secara integratif. Dalam artian seorang guru dapat mengenalkan nilainilai kebaikan, kesadaran akan pentingnya nilai-nilai, dan penginternalisasian nilai-nilai ke dalam tingkah laku peserta didik sehari-hari melalui proses belajar mengajar (Subandi, 2014), pembinaan sehari-hari, bahkan interaksi sehari-hari guru dengan peserta didik dalam lingkungan yang bebas tidak terbatas waktu, baik itu yang berlangsung di dalam maupun di luar kelas (Rozi, 2017).

Pengembangan kurikulum pada hakekatnya diimplementasikan atas dasar beberapa prinsip utama, antara lain sebagai berikut (M. Abdullah, 2019): a. Standar kompetensi Iulusan diturunkan dari kebutuhan.

b. Munculnya standar isi adalah berdasarkan kompetensi lulusan melalui kompetensi inti. Pengembangannya dilakukan berdasarkan monitoring dan evaluasi yang dilakukan secara berkala, sehingga dapat menentukan standar isi yang akan diputuskan selanjutnya.

c. Keputusan dari pimpinan bersama dengan wakil-wakilnya dan bekerjasama dengan seluruh guru, bahwa semua mata pelajaran harus berkontribusi terhadap pembentukan perilaku baik, keterampilan, dan pengetahuan peserta didik.

d. Semua mata pelajaran diturunkan dari kompetensi yang ingin dicapai.

e. Semua mata pelajaran dirancang oleh kompetensi inti.

f. Keselarasan tuntutan kompetensi lulusan, isi, proses pembelajaran, dan penilaian.

Menjadi sangat penting bahwa pendidikan karakter harus ditentukan dan mempunyai tujuan jangka panjang. Pembentukan tersebut harus dipahami melalui proses yang berkesinambungan, yang selalu di-monitoring dan dievaluasiefektifitas dan efisiensinya. Bila tidak sesuai, maka harus dilakukan perubahan-perubahan strategi baru untuk mencapai tujuannya. Pada gilirannya hal itu semua harus fokus pada proses mempertajam visi hidup yang akan diraih peserta didik melalui proses pembentukan karakater diri secara terusmenerus. Tujuan jangka panjang ini harus bersifat aplikatif, yaitu dapat dipahami dan dilakukan oleh segenap tenaga pendidikan bahkan tenaga kependidikan sebuah lembanga pendidikan. Ia tidak boleh hanya sekadar idealisme belaka yang tidak aplikatif. Tidak ada penentuan sarana dan prasarana, tidak ada instrumen, bahkan tidak jelas siapa yang akan melakukan, di mana, dan kapan program pembentukan karakter ini akan dilakukan dalam rangka untuk mencapai tujuan yang diinginkan bersama (Mundiri \& Hasanah, 2018). Karena itu maka semua hal harus jelas yang ditentukan berdasarkan tujuan dan analisis SWOT, sehingga hasil langsung dapat dievaluasi secara objektif" (Fakhruddin, Bahrudin, \& Mujahidin, 2018).

Agar kurikulum pendidikan berbasis karakter dapat dilaksanakan secara optimal, maka kurikulum pendidikan berbasis karakter perlu diimplementasikan melalui langkah-langkah berikut (Ilmu, 2013): 
1. Hendaknya pihak lembaga pendidikan melakukan pendekatan dengan masyarakat secara khusus dan umum, untuk mensosialisasikan program-program yang berkaitan dengan pembentukan karakter yang dirancang secara sistematis. Sasarannya adalah komite sekolah, orang tua, lembaga-lembaga pengguna layanan secara umum, industri-industri, perangkat- perangkat pemerintahan dan lain sebagainya yang mana mereka dapat memberikan kontribusi secara khusus dalam pembentukan karakter peserta didik.

2. Pengembangan pembentukan karakter tersebut bila kita ilustrasikan ke dalam perencanaan kurikulum, yaitu sebagaimana tercantum dalam table berikut (Jumarudin, Gafur, \& Suardiman, 2014):

\section{IMPLEMENTASI PENDIDIKAN KARAKTER}

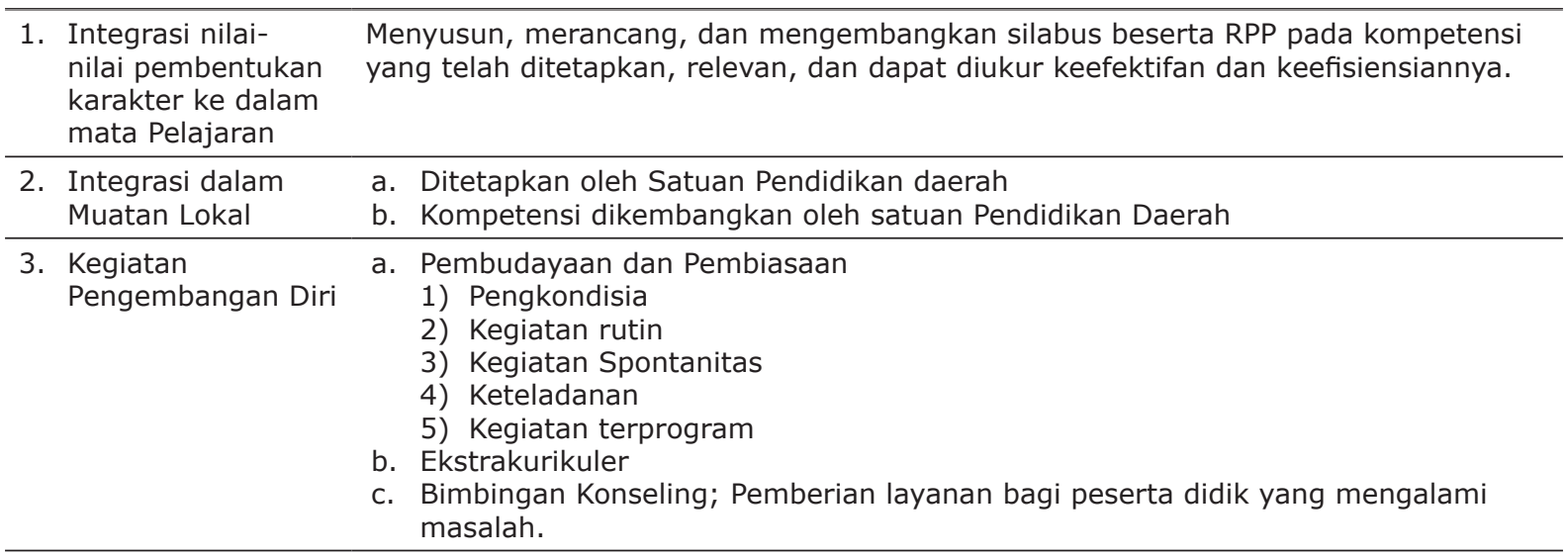

Strategi tersebut diwujudkan melalui pembelajaran aktif dengan penilaian berbasis kelas disertai dengan program pengayaan. Sedangkan pengembangan nilai-nilai karakter diintegrasikan dalam setiap pokok bahasan dari mata pelajaran. Nilai-nilai tersebut dicantumkan dalam silabus dan RPP. Langkah-langkah pengintegrasian dapat dilakukan sebagai berikut (Zuriah, Sunaryo, \& Yusuf, 2016):

a. Mendeskripsikan kompetensi dasar

Kompetensi dasar ini biasanya bersumber pada kurikulum yang berlaku, misalnya institusi pendidikan sekarang menggunakan Kurikulum Berbasis Kompetensi (KBK). Di dalam kurikulum tersebut telah termuat kompetensi dasar untuk tiap mata pelajaran.

b. Mengidentifikasi butir-butir karakter yang akan diintegrasikan

Selanjutnya, dilakukan nilai-nilai karakter yang akan diintegrasikan ke dalam mata pelajaran, misalnya, nilai-nilai karakter jujur, tidak sombong, menghargai orang lain, menjaga, kebersihan, dll.

c. Mengintegrasikan butir-butir karakter ke dalam mata pelajaran (Kompetensi Dasar).
Kemungkinan tidak semua nilai dapat diintegrasikan ke dalam tiap kompetensi dasar dalam suatu pelajaran. Oleh karena itu, perlu mengidentifikasi nilai-nilai karakter yang dimungkinkan dapat diintegrasikan.

d. Melaksanakan Pembelajaran

Pembelajaran dengan pendekatan integrasi perlu dilaksanakan. Metode yang dapat digunakan dalam pembelajaran ini antara lain adalah ceramah, diskusi, penugasan, dll.

e. Menentukan Monitoring dan Evaluasi

Pada dasarnya monitoring dan evaluasi (Monev) dilakukan berdasarkan perkembangan proses yang terjadi dan realistis serta berdasarkan hasil dari kegiatan penanaman karakter terhadap peserta didik. Dari hasil perkembangan perilaku peserta didik tersebut, yang telah dilalui berdasarkan sebuah observasi, tugas-tugas, laporan-laporan dan bahan-bahan lainnya yang mendukung. Maka kemudian seorang guru dapat mengambl suatu keputusan yang tepat, guru dapat memberikan kesimpulan atau pertimbangan tentang pencapaian suatu indikator atau bahkan suatu nilai tentang efektifitas dan efisiensi pembentukan karakter peserta didik melalui perancangan kurikulum berbasis yang dilakukan. 
3. Menentukan sumber belajar; Sumber belajar yang digunakan terutama, buku pegangan guru dan buku pegangan siswa (referensi terkait karakter, alat-alat peraga dsb).

4. Implementasi melalui proses belajar mengajar. Dalam kegiatan belajar mengajar pengembangan karakter terhadap peserta didik dapat dilakukan dengan menggunakan metode belajar aktif seperti belajar kontekstual, pembelajaran kooperatif, pembelajaran berbasis masalah, pembelajaran berbasis proyek, pembelajaran berbasis praktek kerja, dan ICARE (Introduction, Connection, Application, Reflection, Extention). Ini semua dapat dirancang untuk digunakan dalam pembentukan karakter terhadap peserta didik.

Sejak tahun 2015 terjadi perubahan atau inovasi terhadap pengembangan kurikulum menjadi istilah kurikulum 2013. Penyusunannya dimulai dengan menetapkan standar kompetensi lulusan. Pertimbangannya dilakukan atas dasar kesiapan guru dan peserta didik, atas dasar kebutuhan primer dan sebagainya. Setelah kompetensi ditetapkan, kemudian ditentukan kurikulumn yang terdiri dari kerangka dasar kurikulum dan struktur kurikulum. Kesemuanya itu sudah tertuang dalam Peraturan Menteri Pendidikan dan Kebudayaan serta Peraturan Menteri Agama (Kementerian Agama Republik Indonesia, 2018). Dalam hal ini satuan pendidikan dan guru tidak diperkenankan untuk mengembangkannya secara mandiri, semua telah disiapkan oleh Pemerintah Pusat. Guru dapat melakukan langkah inovatif hanya pada konsep RPP (Rencana Pelaksanaan Pembelajaran) saja.

Kemudian berdasarkan pedoman yang dikembangkan oleh BSNP (Badan Standar Nasional Pendidikan) bahwa prinsip-prinsip yang dapat digunakan dalam pengembangan kurikulum berbasis pendidikan karakter adalah sebagai berikut (Fathurrahamn, Staisman, \& Serang, 2016):

1. Berkelanjutan; mengandung arti bahwa proses pengembangan nilai-nilai budaya dan karakter terhadap peserta didik merupakan sebuah proses panjang, dimulai dari awal peserta didik masuk sampai selesai dari suatu satuan pendidikan. Proses tersebut dimulai dari kelas 1 sekolah dasar dan berlangsung paling tidak sampai kelas 9 atau bahkan kelas 10 tingkat Sekolah Menengah Pertama. Pendidikan budaya dan karakter bangsa di SMA (Sekolah Menengah Atas) merupakan kelanjutan dari proses yang telah terjadi selama 9 tahun sebelumnya.
2. Melalui semua mata pelajaran, pengembangan diri, dan budaya sekolah; mensyaratkan bahwa proses pengembangan nilai-nilai budaya dan karakter bangsa dilakukan melalui setiap mata pelajaran, dan dalam setiap kegiatan kurikuler dan ekstrakurikuler.

3. Hal yang berkaitan dengan nilai memang tidak diajarkan secara langsung di kelas-kelas, namun ia dikembangkan. Hal ini mengandung arti bahwa materi nilai budaya dan karakter peserta didik bukanlah bahan ajar biasa, artinya nilai-nilai itu tidak dijadikan pokok bahasan yang dikemukakan seperti halnya ketika mengajarkan suatu konsep, teori, prosedur, ataupun fakta seperti dalam mata pelajaran agama, bahasa Indonesia, PKn, IPA, IPS, matematika, pendidikan jasmani dan kesehatan, seni budaya, dan keterampilan.

4. Hendaknya proses pendidikan yang disusun dan akan dilaksanakan bagi peserta didik ini bersifat aktif dan menyenangkan. Prinsip ini mengemukanan bahwa proses pendidikan karakter yang meliputi perilaku, budaya, dan karakteristik baik ini dilakukan oleh peserta didik didampingi dan dipantau oleh guru dengan prinsip keteladanan (Uswatun hasanah). Guru menerapkan prinsip "tut wuri handayani" dalam setiap perilaku yang ditunjukkan peserta didik. Prinsip ini juga menyatakan bahwa proses pendidikan dilakukan dalam suasana belajar yang menimbulkan rasa senang, nyaman dengan komunikasi yang aktif, dan tidak bersifat pemaksaan yang semenamena. Demikian pula hal itupun perlu masih perlu mempertimbangkan mana yang bersifat pendidikan dan mana yang bersifat doktrin. Karena semua konsep tersebut harus ada dalam dunia pendidikan.

Prinsip-prinsip inovasi pengembangan kurikulum berbasis karakter di atas diharapkan bisa secara konsisten terimplementasikan dengan monitoring yang konsisten dan rutin. Implementasi prinsip-prinsip di atas dapat memberikan jaminan atas sesuainya rencana dengan harapan yang diinginkan terjadi khususnya bagi kelangsung pendidikan bagi anak didik, saat ini dan di masa yang akan datang.

\section{Kesimpulan}

Praktek pendidikan dan pembinaan karakter dalam kegiatan belajar mengajar adalah mengenalkan nilai-nilai, menanamkan kesadaran akan pentingnya berperilaku baik, dan penginter- 
nalisasian nilai-nilai ke dalam tingkah laku peserta didik sehari-hari melalui proses kegiatan belajar mengajar, baik yang berlangsung di dalam maupun di luar kelas.

Adapun langkah-langkah yang dapat diimplementasikan ke dalam kurikulum berbasis karakter antara lain:

1. Melakukan sosialisasi kepada stakeholders.

2. Pengembangan dalam kegiatan sekolah, dengan pengintegrasian sebagai berikut:

a. Mendeskripsikan Kompetensi Dasar.

b. Mengidentifikasi butir-butir karakter yang akan diintegrasikan.

c. Mengintegrasikan butir-butir karakter ke dalam mata pelajaran (Kompetensi Dasar).

d. Melaksanakan Pembelajaran dengan diiringi monitoring yang berkelanjutan terprogram (supervisi).

e. Menentukan Evaluasi.

3. Menentukan sumber belajar dari berbagai referensi yang komprehensif.

4. Implementasi melalui proses belajar mengajar. Dalam kegiatan belajar mengajar pengembangan kurikulum berbasis karakter bagi peserta didik dilakukan dengan menggunakan metode belajar aktif seperti belajar kontekstual, pembelajaran kooperatif, pembelajaran berbasis masalah, pembelajaran berbasis proyek, pembelajaran berbasis praktek kerja, dan ICARE (Introduction, Connection, Application, Reflection, Extention).

Kurikulum dalam pendidikan tidak dapat dipandang sebagai hal yang ideal bersifat tetap, tapi ia terus berkembang sesuai dengan perkembangan kebutuhan warga lembaga pendidikan secara universal dan temporer. Sementara itu, prinsip-prinsip, kedisiplinan, dan monitoring yang konsisten dapat memberikan dukungan yang positif terhadap kelangsungan pengembangan inovasi yang dilakukan terhadap kurikulum yang sangat mungkin selalu berubahubah. Keterlibatan semua pihak dalam hal ini harus mendapatkan perhatian yang penuh, sehingga tidak terdapat kendala di tengah-tengah perjalanan implementasi kurikulum yang berbasis karakter ini. Karenanya selalu perlu dilakukan analisis terhadap perkembangan kurikulum yang dan kebutuhan yang ada dengan selalu mengadakan FGD (fokus Group Discussion) bersama tim dan berbagai pihak yang mempunyai pengaruh dalam hal pengembangan kurikulum.

\section{Daftar Pustaka}

Abdullah, I. (2003). Politik Bhinneka Tunggal Ika dalam Keragaman Budaya Indonesia. Masyarakat Dan Budaya.

Abdullah, M. (2019). School culture to serve performance of Madrasah in Indonesia. Qudus International Journal of Islamic Studies. https://doi.org/10.21043/qijis. v7i1. 4572

Abdurahman, A. (2017). PENGEMBANGAN DESAIN DAN PENDEKATAN PERENCANAAN (PLANNING) DALAM MANAJEMEN PENDIDIKAN ISLAM. AL-TANZIM : JURNAL MANAJEMEN PENDIDIKAN ISLAM. https:// doi.org/10.33650/al-tanzim.v1i2.110

Abdurrahman, A. (2018). Implementasi Manajemen Kurikulum Pesantren Berbasis Pendidikan Karakter. AT-TURAS: Jurnal Studi Keislaman. https://doi.org/10.33650/ at-turas.v4i2.336

Adawiyah, R. (2016). INTEGRASI SAINS DAN AGAMA DALAM PEMBELAJARAN KURIKULUM PAI (Perspektif Islam dan Barat serta Implementasinya). Al-Banjari : Jurnal IImiah IImu-IImu Keislaman. https://doi. org/10.18592/al-banjari.v15i1.817

Akhiruddin, K. (2015). Lembaga Pendidikan Islam di Nusantara. Jurnal TARBIYA.

Bariah, K., \& Assya'bani, R. (2019). Integrasi Nilai Karakter dalam Pembelajaran Akidah Akhlak: Studi Pembelajaran Akidah Akhlak di MI Integral Al-Ukhuwwah Banjang. Al Qalam: Jurnal IImiah Keagamaan Dan Kemasyarakatan, 3. https://doi. org/10.35931/aq.v3i2.169

Fakhruddin, U., Bahrudin, E., \& Mujahidin, E. (2018). Konsep Integrasi dalam Sistem Pembelajaran Mata Pelajaran Umum di Pesantren. Ta'dibuna: Jurnal Pendidikan Islam. https://doi.org/10.32832/tadibuna. v7i2.1394

Fathurrahamn, M., Staisman, D., \& Serang, P. (2016). Efektivitas Implementasi Kebijakan Penyelenggaraan Program Wajib Belajar Madrasah Diniyah Awaliyah Di Kabupaten Pandeglang. TANZHIM Jurnal Penelitian Manajemen Pendidikan Tahun.

Huda, M. B. (2018). Kontrol Nilai Religius dan Humanistis dalam Pendidikan Karakter. Widyabastra, 06.

IImu, J. (2013). PENDIDIKAN AGAMA ISLAM (PAI) DAN KARAKTERISTIKNYA. Jurnal IImu Tarbiyah. 
Jumarudin, J., Gafur, A., \& Suardiman, S. P. (2014). PENGEMBANGAN MODEL PEMBELAJARAN HUMANIS RELIGIUS DALAM PENDIDIKAN KARAKTER DI SEKOLAH DASAR. Jurnal Pembangunan Pendidikan: Fondasi Dan Aplikasi, 2. https://doi.org/10.21831/jppfa. v2i2.2623

Kasali, R. (2015). Self Driving - Menjadi Driver atau Passenger. In Mizan.

Kementerian Agama Republik Indonesia. Peraturan Menteri Agama Republik Indonesia Nomor 9 Tahun 2018 Tentang Buku Pendidikan Agama. , Kementerian Agama § (2018).

Komala, L., Budiyanto, A., Wibowo, W. A., Praditya, A., \& Pamungkas, I. B. (2020). Membangun Kreativitas Dan Kemandirian Masyarakat Di Masa Pendemi Covid - 19. Dedikasi PKM.

Mochammad Arif Budiman. (2017). Pendidikan Agama Islam. Banjarbaru: Grafika Wangi Kalimantan.

Muddin, I. (2019). Pengembangan Bahan Ajar Pendidikan Agama Islam Menggunakan Pendekatan Ilmiah. Jurnal Pendidikan Islam Indonesia, 3. https://doi.org/10.35316/ jpii.v3i2.136

Mundiri, A., \& Hasanah, R. U. (2018). INOVASI PENGEMBANGAN KURIKULUM PAI DI SMP NURUL JADID. Tadrib: Jurnal Pendidikan Agama Islam. https://doi.org/10.19109/ tadrib.v4i1.1721
Nurrohmah, S. (2018). Pengembangan Kurikulum dalam Meningkatkan Pendidikan karakter di Sekolah Dasar. PROSIDING SEMINAR NASIONAL, 1.

Rahman, A. (2012). Pendidikan Agama Islam dan Pendidikan Islam - Tinjauan Epistemologi Dan Isi - Materi. Eksis.

Rozi, S. (2017). Annual International Conference On Islamic Studies. Konstruksi Identitas Islam Perbatasan Sebuah Sintesis Terhadap Identitas Tradisional Dan Identitas Modernis Dalam Paham Keagamaan Di Daerah Rao Sumatera Barat.

Siswanto, S. (2016). DESAIN MUTU PENDIDIKAN PESANTREN. KARSA: Jurnal Sosial Dan Budaya Keislaman. https://doi. org/10.19105/karsa.v23i2.726

Subandi. (2014). Pengembangan Kurikulum 2013 (Studi Analitis dan Subtantif Kebijakan Kurikulum Nasional). Terampil Jurnal Pendidikan Dan Pembelajaran Dasar.

Zuriah, N., Sunaryo, H., \& Yusuf, N. (2016). IbM GURU DALAM PENGEMBANGAN BAHAN AJAR KREATIF INOVATIF BERBASIS POTENSI LOKAL Nurul Zuriah 1 , Hari Sunaryo 2 , Nurbani Yusuf 3. Dedikasi, 13. 